\title{
How Relevant and Useful is the Concept of National Systems of Innovation?
}

\author{
Woojin Yoon ', Eunjung Hyun ${ }^{2}$
}

\begin{abstract}
This paper aimed to provide an analytical and theoretical discussion of the national innovation systems perspective. In doing so, first, we sketched out some of the economists' main endeavours in theorizing about the relationship between technological development and economic progress over the past several decades. Second part of the presentation was concerned with identifying and describing the driving forces behind innovations; that was, an economic actor's desire to gain and sustain competitive advantages. In the third part of the discussion, we presented major theoretical accounts put forward by the authors of national systems of innovation focusing on the question of which institutional elements shape the behaviours and interactions of economic actors in terms of innovative performance. Then we reflected on some of the major policy implications enshrined in the study of national innovation systems.
\end{abstract}

Key words: National innovation systems; knowledge-intensive economy; technological development; innovation policy.

\footnotetext{
' Seoul National University, Institute of Management Research. Shillim Dong, Seoul, I5I-742, Korea. Tel: +82-2-880-6909; Fax: +82-2872-6366. E-mail: yoon.woojin@gmail.com

${ }^{2}$ University of Chicago, Booth school of Business. 5807 South Woodlawn Avenue, Chicago, IL 60637. E-mail:ehyun@chicagobooth.edu

ISSN: 07I8-2724. (http://www.jotmi.org)

Journal of Technology Management \& Innovation (C) Universidad Alberto Hurtado, Facultad de Economía y Negocios
} 


\section{Introduction}

From the late 1980s onwards, we have seen a markedly growing body of literature centred around the concept of, what has been called, 'national innovation systems'. Scholarly work by Freeman (1995), Nelson (1993), and Lundvall (1998), among others, has been usually associated with this concept, and indeed these authors have been frequently credited with inspiring further research interest into this line of inquiry among both academic scholars and policy-makers. Most researchers working under the analytical framework of national systems of innovation appear to subscribe to Nelson's (1993) somewhat broad definition of the term, national systems of innovation, as “... a set of institutions whose interactions determine the innovative performance of national firms" (italic emphasis added). In a similar vein, Lundvall (1992) describes it as "... the elements and relationships, which interact in the production, diffusion and use of new, and economically useful knowledge... and are either located within or rooted inside the border of a nation state." While there is no single, unanimously agreed definition of the concept to date (Archibugi et al., 1999, pp. 528-529; Sharif, 2006) amongst those who adopt the concept, just like many other languages of the social sciences, in our view, the exact meaning of the concept itself seems less problematic for the purposes of this discussion. As such, both definitions are to be followed throughout the presentation simply because we believe that they both convey the important points of the concept sufficiently enough, if not perfectly. Rather, special emphasis will be placed upon the prevailing themes recurring throughout the divergent array of writings on this subject. It needs to be said that this paper is more concerned with exploring the rationale behind the theoretical and analytical concept of national systems of innovation.

It can be argued that the approach of national systems of innovation is profoundly based on three discrete, but intimately interconnected theoretical premises: first, at the most basic level, in most of national innovations system literature technological development is assumed to be the driving engine behind economic progress. Although this view is now taken for granted or, at the very least, widely accommodated amongst many economists as well as scholars with other academic backgrounds guided by the tradition of this research stream, it was not until quite recently that economists have come out with a set of plausible explanations concerning the causality of these two distinct phenomena. Second, the approach of national innovation systems is firmly grounded on the casual observation that economic agents, such as national economies and firms, do innovate predominantly because they are compelled to do so in order to survive and succeed in an extremely competitive environment. To compound this matter further, the recent years have experienced an accelerating pace of globalisation, which leads to, at the very minimum, doubling the extent of competition that domestic firms encounter (Batholomew, 1997; Howells and Michie, 1997; Michie and Prendergast, 1997; Wu and Pangarkar, 2006). Added to this, in recent years there has been an emerging consensus on the amplifying value of knowledge in today's rapidly evolving world economy (Grant, 1996; Nonaka, 1994). Therefore, forces of globalisation coupled with the shift of emphasis towards a knowledge-based economy have set preconditions for our basic understanding of the nature and characteristics of national innovation systems. Third, arguably most important for the purposes of this paper, the approach of national systems of innovation has emanated from the fundamental realization that institutional configurations, more specifically, national institutional contexts matter when it comes to analysing how technological capabilities are built, sourced, diffused, and harnessed (Edquist, 1997; Freeman, 1995; Lundvall, 1998; Nelson 1993). This premise is also intrinsically linked to both first and second assumptions denoted earlier.

Having spelled out the main thrust of the national innovation systems theoretical framework, the question then arises as to how relevant and useful the analytical concept of national innovation systems is in enriching our understanding of real world economies. It seems reasonable to consider that the validity of an analytical framework stems in large part from the extent of its explanatory power. Bearing this criterion in mind throughout the paper, we will attempt to address the question at hand. Broadly speaking, the above three prevailing themes on which national systems of innovation literature rests reflect the overall structure of this paper.

The sequencing of the remainder of the paper is as follows: first, with respect to the first assumption, we shall sketch out some of the economists' main endeavours in theorizing about the relationship between technological development 
and economic progress over the past several decades. Second part of the presentation is concerned with identifying and describing the driving forces behind innovations; that is, the economic actor's desire to gain and sustain competitive advantages. Also included in this section is the role of the idea of a knowledge-intensive economy in reinforcing the perceived need for prompting innovation efforts. Accordingly, some of the key arguments of this strand of theory will be outlined to help enhance our scope for understanding the topic in question. In parallel, we shall account for the arguments for and against the relevance of the national aspect of national innovation systems in this increasingly internationalising world economy. In the third part of the discussion, we shall provide major theoretical accounts put forward by the authors of national systems of innovation focusing on the question of which institutional elements shape the behaviour of and interactions between economic actors in terms of innovative performance. Then we will reflect on some of the major policy implications enshrined in the study of national innovation systems followed by a final word. Needless to say, the choice of work to be included in this discussion inevitably reflects our biases of the important facets of the issue concerned partly due to the enormity of the literature on this subject matter and partly due to the limited space.

\section{Economic Growth and Technological Development}

As Cantwell points out, there has been a rising convergence in the use made of the concepts of innovation and technological development among authors in this subject area (Cantwell, 1992, p.33). It should be noted that this may well be a source of confusion for readers, and can be, to a certain extent, misleading as they are rather two disparate and distinguishable concepts. For one thing, the concept of innovation is broader in scope than that of technological development in that the former encompasses not only technological innovation but also other kinds of innovation, be they organizational or institutional. Ambiguity over the adoption of the terms, to some degree, represents the lack of consensus in the academic discourse of this kind, which, of course, helps stimulate a flurry of debate over the topic. However, a coherent and consistent usage of the key concepts across the literature is of essence if we aspire to bring about more fruitful research outcomes in any foreseeable future. This being said, throughout our discussion, we embrace an extended and now generally accepted view of technological development (indeed, in most of the national systems of innovation literature, these two concepts are for the most part deployed interchangeably) as a multifaceted and multi-layered process entailing all aspects of change required in enabling technology advance. Equipped with this understanding of the concept of technological development, we now move on to shed light on the key line of economic reasoning behind the national innovation systems perspective.

One convenient starting point in this part of the discussion is to trace back where the national innovation systems perspective originated in the field of economics, and seek to uncover major underlying influences at work. At the very core of the thinking behind the analytical framework of national innovation systems, as Hauknes (1999, P. I) acknowledges, are two prominent branches of economic theories; that is, evolutionary theory and institutional theory (See, for example, Dosi and Winter (2002) for an overview of evolutionary theories and Nelson and Sampat (200I) for an overview of institutional theories). In what follows, first, we will briefly take account of evolutionary economists' explanation of economic growth and technological development, and look at the extent to which the study of national innovation systems hinges on this tradition of economic theory. The institutional economic accounts will be tackled later in this discussion, albeit very briefly, when we explore the third theme; that is, the importance of taking stock of its institutional context when analysing a nation's innovation system.

Recent evolutionary theorizing on economic growth and technological change was borne out of a growing disillusionment or, dissatisfaction at best, with the empirical performance of the orthodox neoclassical approach to economic growth (Mulder et al., 200I; Lundvall, 1998). It is now widely known that the foundations of the evolutionary models were laid down in the seminal work of Nelson and Winter (Mulder et al., 2001; Nelson, 1993, Pp. 513-514; Nelson and Winter, 1982). Simplifying somewhat, the key criticisms labeled against the dominant neoclassical theory are twofold: ${ }^{3}$

\footnotetext{
${ }^{3}$ Part of the criticism of neoclassical models of economic growth has been superseded by the emergence of the endogenous growth theory that is still in the neoclassical strand of thinking. Endogenous growth theory endogenise technological change;
} 
evolutionary economists, first, ardently argue that the traditional economic growth theories are built upon too much stylised, stripped down, abstract assumptions, and thus treat economic growth as something of "a smooth process involving a continuous tendency to return to an equilibrium state" (Mulder, 2005, p. 28). It can be noted that this sort of criticism is frequently made by a number of other unorthodox economic thinkers as well. Yet, detailed discussion of this issue, albeit important, is beyond the scope of this paper. Second, proponents of the evolutionary economic perspective are very sceptical of the fact that in the neoclassical growth models technological progress is assumed to be exogenous, and given, thereby neglecting the very force underpinning the observable reality of an uneven economic growth (Mulder et al., 200I). In the parlance of evolutionary economic theorists, the neoclassical growth theory "explains growth by simply postulating its existence" (Mulder, 2005, p. 17). In response to these shortcomings manifested in the neoclassical analysis of the role of technological change in economic growth, evolutionary theorists propose a more realistic description of the complex process of technological progress based on not some abstract ideas but real empirical observations.

The empirical findings of the recent evolutionary perspective on the sources, procedures, directions, and efforts of technological development can be summarized as follows: first, innovative efforts are characterized by varying degrees of appropriability and uncertainty about the technical and commercial outcomes (Dosi et al., 1990). It is worth noting that these characteristics of innovation have attracted a good deal of attention, especially, from the contemporary literatures of strategic management and innovation studies as they tend to have a direct bearing on firm-level strategising (Afuah, 2002; Pisano, 2006; Teece, 1986). Put differently, these salient features of innovations invoked such questions as how firms can best leverage uncertainty inherent in an innovative activity, how firms can continue to profit from their innovations, among many others. In this discussion, again, we are not very much concerned with innovation processes at the micro-level

Arrow endogenise technology by assuming that the growth rate of the effectiveness of labour is a result of workers' cumulative experience in producing commodities, or in other words, the result of learning by doing (Mulder et al., 200 I, pp. 168-175). although we recognize the important role played by a firm or firms as a prime locus of innovation within a national innovation system. Naturally, we are in need of research efforts aiming at integrating both micro- and macro-levels analysis in order to fully grasp this complex phenomenon.

Second, it is now readily understood that technology embodies a certain degree of tacit knowledge that is local and cumulative (Kogut and Zander, 1993; Nonaka 1994). Third, it also follows that innovations typically result from search and learning processes of individuals or organizations, and in turn knowledge building and problemsolving activities are ingrained in organizational or behavioural routines. This dimension of technological development now features prominently in national innovation systems literature. Especially since early 1990s, many researchers have been grappling with knowledge and learning aspects of an innovation system, and have started to delve deep into this issue by heavily relying on analytical and conceptual tools borrowed from other fields of inquiry such as organizational learning, epistemology, behaviour psychology, and the like. We will be taking up this issue at some length later in the discussion.

Fourth, exponents of the evolutionary economic theory hold that technologies develop along relatively ordered trajectories within the boundaries of the organizations and technological paradigms as a result of three characteristics just discussed. Here, technological paradigms, according to Dosi et al. (1990), refer to “... a collective framework that determines the R\&D practice and the pattern of technological development on the basis of a dominant design of an artefact..." Consequently, “... technologies may well get locked-in to paradigms, implying a certain degree of path dependency and irreversibility". ${ }^{4}$ This is a

\footnotetext{
${ }^{4}$ Path dependency implies the role of historical events in determining the adoption of technologies. Innovation and diffusion of technologies displace older technologies imposing irreversible losses to the agents that are locked-into outdated technologies, in line with this, the existence of vested interests among agents specialized in the old technologies may cause resistance to the adoption of new technologies and hence slow down technological progress (Mulder et al., 200I). Even where the existing standard is inherently inferior, replacing it may be exceedingly difficult. The case of typewriter keyboard is classic. The standard QWERY arrangement was invented in 1873. It was designed to slow the speed of typing to prevent the typing bards on mechanical typewriters from locking together. In 1932, the DSK was patented and was shown to offer considerable gains in
} 
very important point not least because it has some crucial policy implications connected to what kind of policy measures at both micro- and macro levels are necessary in order to induce and trigger a certain class of technological development. Also, intrinsic in this notion of evolutionary trajectories of technological change is the appreciation that the context of technological development needs to be read in order to make better sense of it.

The evolutionary view, taken together, can be said to exemplify a Schumpeterian perspective on economic growth and technological progress (Hauknes, 1999; Mulder et al., 200I; Nelson, 1995). ${ }^{5}$ Still, it is subject to considerable debates whether the evolutionary theory is better positioned to expose the complex process of technological change in a satisfactory manner compared to other economic growth theories. Nevertheless, it is not our intention here to weigh the merits and demerits of each economic assertion in any depth. The evolutionary camp's claim that they offer a more sophisticated microeconomic foundation for explaining macroeconomic patterns, however, may prove valid in so far as such fertile research projects as national innovation systems approach continue to surface under its influence. It is within this context that we now turn to the next part of the presentation pertaining to the second theme of the national innovation systems perspective.

\section{Competitiveness, Globalisation and the Importance of Knowledge}

Here we aim to identify and describe the driving forces behind innovations; that is, an economic actor's desire to

typing speed. The QWERTY keyboard has persisted because people were locked-into it and its enormous network effects were reinforced by the investment of millions of people in touch typing and manufacturers in keyboard layouts (David, 1985).

${ }^{5}$ Schumpeter (1934) pioneered the theory of economic development and new value creation through the process of technological change and innovation. He viewed technological development as discontinuous change and disequilibrium resulting from innovation and identified several sources of innovation including the introduction of new products and new production methods, the creation of new markets, the discovery of new supply sources and the reorganization of industries. He (1942) introduced the notion of creative destruction noting that following technological change certain rents become available to entrepreneurs, which later diminish as established practices in economic life (Amit and Zott, 200I). gain and sustain competitive advantages. Also included in this section is the role of globalisation and the idea of a knowledge-intensive economy in reinforcing the perceived need for prompting innovation efforts. We have shown in the preceding section that there has emerged a general, although not unanimous, agreement over the positive impact of technological advance on economic development. This then begs another question of why technological advance ever occurs in the first place. In other words, what motivates and prompts economic actors to relentlessly pursue technological advance. Most scholars in this area of research tend to address this question in terms of a mounting pressure of competition. While discussing competitive advantages at the firm-level seldom causes little controversy, the notion of national competitive advantages has raised some doubts among economists. Krugman (1994), most notably, argues against the concept of competitiveness at the national level altogether. He puts it "... the idea that a country's economic fortunes are largely determined by its success on world markets is a hypothesis, not a necessary truth; and as a practical, empirical matter, that hypothesis is flatly wrong. That is, simply not the case that the world's leading nations are to any important degree in competition with each other, or that any of their major economic problems can be attributed to failures to compete on world markets". In arguing so, he displays some empirical evidence for the apparent lack of significance of trade performance for living standards in the US, and asserts that the same results hold for the European countries and Japan. In addition, he succinctly pinpoints that obsession with national competitiveness is dangerous, and can escalate into unnecessary trade conflict. Subsequently, his argument against the idea of a nation's competitiveness has invited sizeable attention from both academic researchers and policy practitioners.

Krugman's acute contention notwithstanding, little dissension, in effect, has come to light pertinent to the existence of national competitiveness. Whether the concept of national competitive advantages is warranted or not is apparently more of an empirical question. Nevertheless, it is worthwhile to note that what matters most, especially to policy-makers, may not be actual competition per se, but rather, their perception of competition, be it actual or potential. Hence conscious efforts to outperform competitors by gaining and sustaining competitive advantage are most likely to remain intact.

ISSN: 07 I 8-2724. (http://www.jotmi.org)

Journal of Technology Management \& Innovation (C) Universidad Alberto Hurtado, Facultad de Economía y Negocios 
On the other hand, Porter (1990) designates four interdependent, mutually reinforcing attributes of a nation as the major determinants of competitive advantages. They are I) factor conditions, such as the availability of skilled labour force and infrastructure, 2) demand conditions for the products of the industry, 3) related and supporting industries, and 4) firm strategy, structure and rivalry. National competitiveness, he goes on to argue, resides in the extent of pressure which these four intertwined factors exert on firms to invest and innovate. Thus, while the competitiveness of firms will obviously reflect the degree of successful internal management of firms themselves, their competitiveness is also unavoidably contingent upon the country-specific conditions within which they operate. Implicit in this argument is that the competitive advantage of firms and of the economies as a whole is something, which is and can be built up by conscious and deliberate policy actions. In parallel, Nelson notes that a strong belief has lingered on inside circles of academia and policy makers that technological prowess is a key source of competitiveness (Nelson, 1993).

So far, we have looked at two opposing views on the idea of the competitiveness of a nation. In brief, whereas it is still susceptible to much more debates whether the concept of national competitiveness as such is duly qualified or not, there exists little disagreement over the view that identifies competition as the force pushing technological development forward. Having recapped the points made so far, now the attention needs to be diverted to a more important issue for the aims of this paper; namely, how the theoretical insights of national innovation systems permit us to better apprehend a complex process of innovation in this ever-increasingly evolving global and knowledge-based economy. In unravelling this rather intricate question, first, we highlight the existence of inherent tension between the internationalising trend of technology and the continued relevance of national frameworks. And in order to assist our understanding of far-reaching effects on the study of innovation of the increasing emphasis on the so-called a knowledge-based economy or a learning economy, a brief review of some principal matters persistently appeared in the knowledgebased view of the firm will be introduced (Grant, 1996).

Undoubtedly, the economic life has become global on a hitherto unprecedented scale as testified to by rapidly soaring trade and investment volumes across national borders (Batholomew, 1997; Howells and Michie, 1997; Metcalfe, 200I). Added to this, the role of transnational corporations has been extensively stressed in altering the face of the world economy in the direction of globalisation (Batholomew, 1997; Cantwell, 1992). Ohmae (1990) is often quoted to argue that "... national borders are losing their meaning as economic frontiers ", and technology is becoming a product of what he calls 'interlinked economy' (Batholomew, 1997; Howells, 1997). While some advocates of globalisation concede, although somewhat unwillingly, that global integration and local differentiation may not stand at the opposite ends of the single continuum, the recent years have observed the growing divide arising between proponents and opponents of globalisation (Baker et al., 1998; Hirst and Thompson, 1999; Westerfield, 2004). Against this backdrop, as Archibugi et al. (1999, pp. 533-534) point out, the whole concept of enduring national differences, particularly in innovative capabilities, shaping national innovative performance has been intensely challenged by those who underscore the internationalisation of many of our economic activities. For example, sceptics of the national aspect of the national innovation systems framework contend that the phenomenal growth of international R\&D networks signal the convergence of technological capabilities across countries. It is, to a large extent, a matter of detailed empirical study whether or not the heightening of cross-national R\&D activities through various kinds of arrangements including joint ventures, strategic alliances, consortia, renders the notion of durable national differences in their technological capabilities redundant.

At this point, it will be of great use to briefly outline some of the methodological and analytical issues surrounding empirical studies of this subject matter. First, while the conventional approach to measuring and quantifying innovative performance at an aggregate level, which is primarily based on a simple input and output method, say, R\&D expenditures vs. number of patent produced, has been gradually abandoned by researchers working in this field, no plausible alternative methods have as yet taken its place. ${ }^{6}$ This, critics would argue, often leads to a weakening

${ }^{6}$. Freeman points out "... purely quantitative indicators such as R\&D expenditures as a proportion of GNP or patent statistics are rough measures innovative activities, they do not in themselves explain how these activities led to higher quality of 
of the analytical power of the national systems of innovation framework or the whole systemic approaches for that matter. Nonetheless, the recent years have seen a series of ongoing research efforts, which attempt to remedy precisely this kind of problem by bringing together the various set of indicators corresponding to each innovative activity.

A Second issue is of level of analysis, which has a direct bearing on our topic. Over the past decade the national systems analysis has been extended to different levels including supra-national and sub-national as well as sectoral and technological. What is central here is to note that there remain substantial industrial and regional variations even within the national innovation systems. ${ }^{7}$ While some would still argue for the supremacy of one level of analysis against another on methodological as well as substantive grounds, it has been incrementally recognized that innovation systems analysis at different levels may not necessarily incompatible, but rather complementary, serving various uses and purposes of analysis. In the global vs. national argument, without an extensive empirical backing it is no doubt difficult to judge the validity of each analysis against another. Although, to a certain extent, the dichotomy of global vs. national seems inevitable, there is a need to shift the focus towards a more integrative approach. Batholomew

new products or processes, to shorter lead time and to more rapid diffusion of technologies ..." (1995, p. 15).

7. Nelson (1993) also points out that there are important interindustry differences in the nature of technological change, the sources and how the involved actors - upstream and downstream firms - are interrelated to each other. Technical advance in industries engaging in producing a complex system in terms of the number of the critical components - such as an aircraft - tends to proceed through a combination of improvements in components, and modifications in overall system design to exploit this, punctuated by occasional introduction of a radically new system. The integration of component and systems innovation activities generally involves some combination of independent initiatives mediated by the market, contracting and cooperation. Whereas technical advance in the industries producing fine chemical products, from synthetic materials to pharmaceutical, involves the introduction of discrete new products, that are subject to the discovery of new uses by producers or users. Other industries that are engaged in bulkproducing activities evolve relatively slowly in terms of innovation, and technical change in those fields usually means improved, or sometimes new, ways of producing the product concerned.
(1997) argues that the central question is how countryspecific innovation systems are intertwined within the global system and the particular characteristics of national systems of innovation form the basis for complex interdependence in the global system.

Third, there has been a call for more systemic approaches to the study of national innovation systems (Archibugi et al., 1999; Hauknes, 1999; Lundvall, 1998; Nelson, 1993). To date, one of the most extensive studies of national innovation systems covering 15 different capitalist economies is well documented in Nelson (1993)'s edited volume. Comparative studies of 15 countries that are categorized into the large market-oriented industrialized nations, smaller high-income countries, and newly industrializing states to illuminate the overall mechanisms by which technical innovation is supported, enhanced and shed light on the similarities and differences across those countries (Nelson, 1993). Interestingly, Liu and White (200I) argue in their discussion of the Chinese innovation system that although purporting to analyse systems, “... most scholars have actually focused on the roles of specific actors and the impact of specific policies and institutions to explain system-level outcomes - no way to describe alternative system level structures of which actors and institutions are only elements and hence no way to make comparisons among alternative systems".

In the preceding discussion, first and foremost, we have looked at a recent surge in the emphasis on innovative performance, particularly that of a nation, in the context of intensifying globalisation. Although we have not dealt with the issue of a current trend towards globalisation of technology (Archibugi and Michie, 1995) at any length here, it seems reasonable to say that measurable and certainly observable global dimension of at least some of industrial innovative systems should not be overlooked. In the discussion which follows, we will move our emphasis into another salient feature of modern economies; namely, the knowledge-based economy.

Recent hype revolving around the idea of the importance of knowledge has spurred a great deal of attention on this issue. Generally speaking, an increasing number of social science disciplines, let alone the national innovation systems approach, have shifted their focus towards the importance of knowledge as a driving force behind broader

ISSN: 07I 8-2724. (http://www.jotmi.org)

Journal of Technology Management \& Innovation () Universidad Alberto Hurtado, Facultad de Economía y Negocios 
economic changes. In the management discipline, what is now named as 'the knowledge-based view of the firm', which views the raison d'etre of a firm as knowledge creation, has started growing as a separate field of inquiry (Grant, 1996; Leonard-Barton, 1995; Nonaka, 199I, 1994; Quinn, 1992). The knowledge-based view of the firm can be seen as a perspective combining insights from the socalled 'resource-based view of the firm' with those from organizational learning theories (Grant, 1996). More recently, there have been new intellectual developments, which attempt to synthesize the received findings of innovation studies into a knowledge-based perspective on technical change (Carayanis et al., 2000; Asheim and Coenen, 2005; Hekkert et al, 2007).

Here, we will capitalise on some theoretical insights of relevance from the knowledge-based view of the firm and the field of organizational learning. Many researchers have heavily drawn upon Polanyi's distinction between tacit knowledge and explicit knowledge in an effort to widen their understanding of the complex process of knowledge creation, diffusion and utilization (Coombs and Hull, 1998; Grant, 1996; Nonaka, 1994; Carayanis et al., 2000). ${ }^{8}$ This distinction, albeit somewhat blurry, supplants conventional economists' rather limited notion of knowledge as public good with un-rivalriness in its consumption pattern (Nonaka and Takeuchi, 1995). ${ }^{9}$ Interest in tacit knowledge has grown rapidly as studies of technological innovation have increasingly recognized it as an important component of the knowledge base in innovative activity. To a large extent, reconceptualising knowledge along this tacit explicit dimension enables us to better appreciate

${ }^{8}$. Explicit knowledge is readily articulative, codifiable, transferable and objective whereas tacit knowledge is not easy to articulate, codify, transfer because it is action-based, experience-based and embedded in social fabric (Grant, 1996; Nonaka, 1994). The knowledge of the firm can be analysed along two dimensions; the epistemological and ontological. The former is concerned with the manifestation or modes of expression of knowledge, namely, Polanyi's distinction between explicit and tacit. The latter is about the locus of knowledge or the knowing entity within the firm knowledge can reside at the level of the individual or the collective (Nonaka, 1994).

9. Firm which captures and exploits unique and valuable knowledge capabilities will tend to attract more knowledge creating assets such as expert employees, thus exhibiting increasing returns. Non-rivalry means one's consumption not diminishing another's consumption. So knowledge is not transferred in a formal sense; it is shared (Carayanis et al., 2000). multifaceted innovation processes in terms of mobility, transferability and reproducibility of particular knowledge in question. From an empirical standpoint, most researchers are acutely aware that inherent disadvantages of an empirical research relying on analysis of knowledge flow processes lie in the practical difficulty of quantifying the stock of knowledge and its flow with any measure of accuracy. Batholomew (1997)'s comparative analysis of the US, UK, German and Japanese systems of biotechnology innovation systems can be viewed as a partial attempt to overcome this kind of problem since her analysis of knowledge flows amongst intertwined actors is predominantly based on qualitative data.

Another important facet of tacit knowledge tied to innovation is, as Howells (1997) points out, “... its localized patterns of learning and sharing which provide a strong element in this spatial stickiness of innovation and technology transfer" (italic emphasis added). To put it another way, the extent to which tacit knowledge constitutes the knowledge base of an economic agent, and how it is formed and exploited are overwhelmingly shaped by the broader social and institutional settings. At the micro-level, in view of Carayanis et al. (2000), the knowledge of a firm is socially embedded, rooted in coordination mechanisms and organizational routines which in turn are profoundly influenced by societal institutions such as education and training systems, and types of labour markets. Thus, the recognition of the crucial role played by tacit knowledge in the process of innovation and its embeddedness in a societal milieu naturally directs our attention to the final of the discussion.

\section{Tacit knowledge, Interactive Learning and Institutions}

In what follows, we seek to combine the theoretical insights of the evolutionary economic perspectives and the knowledge-based view of the firm that we have reviewed throughout the previous discussion into a coherent whole in an attempt to understand the broader context where the concept of national innovation systems resides. What seems striking in terms of these two different perspectives and the national innovation systems approach is the degree of commonality they all share in their emphasis on the importance of institutional context, or more generally, of

ISSN: 07I 8-2724. (http://www.jotmi.org)

Journal of Technology Management \& Innovation (C) Universidad Alberto Hurtado, Facultad de Economía y Negocios 
societal context. In Hauknes words (1999, p.I), the innovation systems literature “...reflects Marx's broad conceptions of the economy as a social process...". In hindsight, it is not surprising that the research agenda of the national innovation systems approach has been multidisciplinary in scope as it is predicated on the very belief that a full-fledged understanding of economic behaviours and its driving forces can not be achieved without appropriate consideration of a wider social setting. The research into the national systems of innovation has been also mirrored in the study of what has been referred to as 'social systems of production', which in turn has been deep-seated in the wider study of the evolution of capitalism. Hollingsworth's (1997) comparative analysis of the social production systems of US, Germany and Japan can be viewed in this light. It is worthy of a mention that it can be rather arbitrary and artificial to describe a national system of innovation as something neatly separable from its production system, and economic system more broadly. Nelson (1993) also argues that it seems inevitable that analysis of innovation in a country often would get drawn into discussion of industrial relations systems, financial system, government policies that span from monetary, fiscal, industry, science and technology, education. It is not easy to draw a clear line around those aspects of a nation's institutional structure that are concerned predominantly with innovation in a narrow sense. Lundvall (1998) addresses this concern by highlighting that to focus on a specific aspect of economic life can result in more fruitful research outcomes than to adopt a seemingly allencompassing concept (Lundvall, 1998).

Next, we offer an institutional account of national innovation systems in a brief manner, and then move on to the recent emphasis on the importance of interactive learning in innovation. In general, literature on national innovation systems has sought to link national institutions to the innovative performance of firms and national economies (Freeman, 1995; Lundvall, 1998; Nelson, 1993). ${ }^{10}$ The institutional theorists define institutions as

10. Nelson (1993) argues how technological capabilities are advanced extends far beyond those directly impinge on innovation. The character and effectiveness of a nation's system of schooling, training, and retraining not only shape the supply of skills, but also affect the attitudes of workers towards technical advance. So too do the industrial relations system - the relations between labour and management, patterns of bargaining and "systematic patterns of shared expectations, taken-forgranted assumptions, accepted norms and routines of interaction that have profound effects on shaping the motivations and behaviour of interconnected social actors" (Chang, 1994, p.84; for more detailed account on institutional theories from various perspectives, see DiMaggio, 1998; DiMaggio and Powell, 1991; Dosi and Coriat, 1998; Hodgson, 1988; North, 1991;). This definition, to a great extent, is consistent with what is used in the national innovation systems literature. In her study of biotechnology innovation systems of different countries, as mentioned earlier, Batholomew (1997, p. 243) illustrates that “... national patterns in biotechnology R\&D are primarily shaped by the configuration of country-specific institutional features ... and the particular national path of technological development in turn reinforces country-specific patterns of organization...". For instance, she shows how individualistic, commercially-oriented and self-sufficient characteristics of US socio-political institutions motivate or hamper innovative activities of the US biotechnology industry as opposed to those of UK, which are more pluralistic but much less commercially-oriented.

Within the literature of national innovation systems, Lundvall's work (1998) has been particularly influential in stressing "the specificity and interconnectedness of societal institutions bearing on the processes of interactive learning and innovation" (Archibugi et al., 1999; Hauknes, 1999). Lundvall (1998) claims that the innovative capacity of an economic entity is a direct function of its learning ability and it can be in large part attributable to the density and quality of learning networks within a system of innovation. From this standpoint, it is readily observable that the flow of knowledge, especially that of tacit nature, tends to face fewer impediments within a social milieu that is easily accessible, spatially concentrated, and in which constant and repeated interaction is encouraged. Another important aspect is that, according to organization learning theory, the effective interactive learning process entails all participants to have similarly structured absorptive

negotiation, dispute resolution, and degrees of mutual commitment of firms and workers. Financial markets and the dominant mode of corporate governance also have strong bearings on the technical activities that are feasible and that managers choose to undertake. 
capacities (Bogenrieder and Nootebook, 2004; Cohen and Levinthal, 1990; Greve, 2005).

Several authors draw on the concept of social capital to illuminate how to build and maintain effective learning networks vital to successful innovative activities in the increasingly knowledge-driven business environments (e.g. Dhanaraj and Pharke, 2006). It is argued that trust and the realization of mutual benefits accrued from cooperation among different participants can be geared up for a wave of successive collaboration, and thus tend to lead to an effective learning. Here, it is worth looking at how cooperative behaviour and interactions, other than arm's length relationship with markets, that run counter to its basic premise of individuals as highly self-seeking beings driven by instrumental rationality, are explained in the mainstream economic theory. In the view of mainstream economists, because knowledge is often dispersed unevenly, pure competition, which deters economic agents from sharing knowledge, leads to sub-optimal outcomes. They go on to argue that treating one's apparent and potential rivals as complementors, seeking to cooperate with them and well managing those relationships can turn a zero-sum situation into a positive sum situation. Furthermore, in the language of transaction cost economics, "strong form of trust provides a more efficient and effective basis for a cooperative relationship, as it decreases reliance on governance mechanisms with high transaction costs but provides more comprehensive protection against opportunistic behaviour" (Carayanis et al., 200I)." As noted in the above discussion, however, this rather over-simplistic view of the dynamics of social process often causes uneasiness among critics (Lundvall, 1998).

In summary, from the perspective of national innovation systems, as Batholomew stresses, country-specific

\footnotetext{
'I. Trust refers to mutual expectations regarding consistency in behaviour and full revelation of relevant information and to loyalty in difficult times. Like any form of collective action, collaboration is also subject to opportunistic behaviour by some members. This can degenerate into another form of competition with each trying to maximize its gains but minimizing the sharing. One way to guard against such opportunistic behaviour is to approach the knowledge sharing as an exchange rather as a transfer - two way transaction where involved parties benefit in an approximately equal fashion - reciprocal - the existence of some norm of reciprocal behaviour - implying a level of strong form trust exists among participants (Carayanis et al et al., 200I).
}

innovation trajectories are shaped, or at least influenced, by the structural components of its society, which profoundly affect the accumulation and diffusion of knowledge required for industrial innovation (Batholomew, 1997). Links between knowledge and innovative performance can be scrutinised by "... focusing on firmspecific routines which stabilize certain bodies of knowledge and then embed them in the shared understanding within the firm..." (Coombs and Hull, 1998, p. 238). At the foundations of the multifaceted innovation processe is the significance of the dynamic relationship between individual and collective learning (Lundvall, 1998).

\section{Conclusion}

At the outset, we have set out to provide an analytical and theoretical discussion of the national innovation systems perspective. On balance, with an understanding of the positive correlation between technological development and economic growth informed by the evolutionary economic perspective, we have explored two key factors behind current emphasis on industrial and technological innovations; namely, increasing forces of globalisation and shift toward a knowledge-intensive economy. In tandem, recent stress on the importance of tacit knowledge has given rise to a substantial body of literature that is focusing on knowledge flows and learning networks within a national innovation system among different economic agents including university research labs, public R\&D labs, industrial R\&D labs, foreign R\&D labs, and the like. We have described major theoretical insights on which these new intellectual developments build, especially in relation to the knowledge-based view of the firm and organizational learning theories. Metcalfe (200I) elegantly puts this entire theme, “ $\ldots$ the ceaseless economic movement and transformation across time and space, which is capitalism's defining feature, follows from the nature of knowledge accumulation in general and the institutions that shape the growth and application of scientific and technological and social knowledge in particular...".

In the final analysis, it should be noted that implicit in the majority, if not all, of the literature on national innovation systems is that there is a need for active government involvement, nationally, locally and even globally, in terms of industrial policy, in general, and innovation, science \& technology, education and regional policies, in particular. 
This, in turn, potentially evokes one of the most contentious issues in the modern economic debate; namely, the free market vs. government intervention. Unfortunately, this topic is outside the scope of this discussion.

\section{Reference}

AFUAH, A. (2002). Innovation Management: Strategies, Implementation and Profits. $2^{\text {nd }}$ ed. Oxford University Press, New York.

AMIT, R., Zott, C. (200I). Value creation in E-business. Strategic Management Journal, Vol.22, pp.493-520.

ARCHIBUGI, D., Howell, J. Michie, J. (eds.), (1999). Innovation System in a Global Economy. Cambridge University Press, Cambridge.

ARCHIBUGI, D., Michie, J. (1995). The globalisation of technology: a new taxonomy. Cambridge Journal of Economics, Vol.19, pp. I2I-140.

ASHEIM, B.T., Coenen, L. (2005). Knowledge bases and regional innovation systems: Comparing Nordic clusters. Research Policy, Vol. 34, pp. II 73-I 190.

BAKER, D., Epstein, G., Pollin, R. [eds.] (1998). Globalisation and Progressive Economic Policy. Cambridge University Press, New York.

BATHOLOMEW, S. (1997). National systems of biotechnology innovation: complex interdependence in the global system. Journal of International Business Studies, Vol.2, pp. 24 I-265.

BOGENRIEDER, I., Nootebook, B. (2004). Learning Groups: What Types are there? A Theoretical Analysis and an Empirical Study in a Consultancy Firm. Organization Studies, Vol. 25, 287-3I3.

CANTWELL, J. (1992). The theory of technological competence and its application to international production. In: McFetridge, D. (ed.). Foreign Investment, Technology and Economic Growt. University of Calgary Press, Calgary. Pp. 33-67.
CARAYANIS, E.G., Alexander, J., loannisis, E. (2000). Leveraging knowledge, learning, and innovation in forming strategic government - university - industry RandD partnerships in the US, Germany and France. Technovation, Vol.20, pp. 477- 488 .

CHANG, H. (1994). The Political Economy of Industrial Policy. Macmillan Press, London.

COHEN, W., Levinthal, D. (1990). Absorptive capacity: a new perspective on learning and innovation. Administrative Science Quarterly, Vol.35, pp. I28-I52.

COOMBS, R. Hull, R. (1998). Knowledge management practices and path-dependency in innovation. Research Policy, Vol.27, pp. 237-253.

DHANARAJ, C., Pharke, A. (2006). Orchestrating innovation networks. Academy of Management Review, Vol. 3I, pp. 659-669.

DAVID, P. (1985). Clio and the economics of QWERTY. American Economic Review, Vol.75, pp. 332-337.

DIMAGGIO, P. (1998). The new institutionalism: avenues of collaboration, Journal of Theoretical and Institutional Economics, Vol.I54, pp.696-7I5.

DIMAGGIO, P., Powell, W. (199I). The iron cage revisited: institutional isomorphism and collective rationality in organisational fields. In: DiMaggio, P., Powell, W. (eds.), The New Institutionalism in Organisational Analysis. University of Chicago Press, Chicago. pp. 63-82.

DOSI, G., Coriat, B. (1998). The institutional embeddedness of economic change: an appraisal of the evolutionary and regulationist research programmes. In: Nielsen, K. and B. Johnson (eds.), Institutions and Economic Change: New Perspectives on Markets, Firms and Technology, Edward Elgar, Aldershot. pp. 33-55.

DOSI, G., Pavitt, K., Soete, I. (1990). The economics of technical change and international trade. New York University Press, New York.

DOSI, G., Winter, S. (2002). Interpreting economic change: Evolution, structures and games. In: Augier, M. and J. March (eds.), The Economics of Choice, Change, and 
Organizations. Edward Elgar Publishers, Cheltenham. Pp. 337-353.

EDQUIST, C. (ed.), (1997). Systems of Innovation. Pinter, London.

FREEMAN, C. (1995). The national systems of innovation in historical perspective. Cambridge Journal of Economics, Vol. 19, pp. 5-24.

GRANT, R. (1996). Towards a knowledge-based theory of the firm. Strategic Management Journal, Vol. 17, (Winter Special Issue), Pp. 109-122.

GREVE, H.R. (2005). Interorganizational learning and heterogeneous social structure. Organization Studies, Vol. 26, 1025-1047.

HAUKNES, J. (1999). Innovation Systems and Capabilities. No A 1099, STEP Working paper series, The STEP Group, Studies in technology, innovation and economic policy, http://econpapers.repec.org/RePEc:stp:workin:al 099.

HIRST, P., Thompson, G. (1999). Globalisation in Question. Polity Press, Cambridge.

HEKKERT, M.P., Suurs, R.A.A., Negro, S.O., Kuhlmann, S., Smits, R.E.H.M. (2007). Functions of innovation systems: A new approach for analysing technological change. Technological Forecasting and Social Change, Vol. 74, pp. 4I3432.

HODGSON, G. (1988). The approach of institutional economics. Journal of Economic Literature, Vol. 36, Pp.166192.

HOLLINGSWORTH, J. (1997). Continuities and changes in social systems of production: the case of Japan, Germany, and United States. In: Hollingsworth, J. and R. Boyer (eds.), Contemporary Capitalism: The Embeddedness of Institutions. Cambridge University Press, Cambridge.

HOWELLS, J. (1997). Rethinking the market-technology relationship for innovation. Research Policy. Vol. 25, pp.1209-1219.

HOWELLS, J., Michie, J. [eds.] (1997). Technology, Innovation and Competitiveness. Edward Elgar, Cheltenham.
KOGUT, B, Zander, U. (1993). Knowledge of the firm and the evolutionary theory of the multinational coroporation. Journal of International Business Studies, Vol. 24, pp. 625-645.

KRUGMAN, P. (1994). Competitiveness: A dangerous obsession, Foreign Affairs, March/ April, Vol, 73, pp. 28-44.

LEONARD-BARTON, D. (1995). Wellsprings of Knowledge: Building and Sustaining the Sources of Innovation. Harvard Business School Press, Boston.

LIU, X., White, S. (200I). Comparing innovation systems: A framework and application to China's transitional context. Research Policy, Vol.30, pp. I09I-III4.

LUNDVALL, B.-Å. [ed.] (1992). National Systems of Innovation: Towards a Theory of Innovation and Interactive Learning. Pinter Publishers, London.

LUNDVALL, B.-Å. (1998). Why study national systems and national styles of innovation? Technology Analysis and Strategic Management, Vol. I0, pp. 407-422.

METCALFE, J. (200I). Institution and Progress. Industrial and Corporate Change, Vol.I0, pp. 56I-585.

MICHIE, J., Prendergast, R. (1997). Innovation and competitive advantage. In: Howells, J. and J. Michie (eds.), Technology, Innovation and Competitiveness. Cheltenham: Edward Elgar.

MULDER, P. (2005). The Economics of Technology Diffusion and Energy Efficiency. Cheltenham: Edward Elgar.

MULDER, T., De Groot, H.L.F., Hofkes, M.W. (200I). Economic growth and technological change: a comparison of insights from a neo-classical and an evolutionary perspective. Technological Forecasting and Social Change, Vol. 68, pp. $|5|-|7|$.

NELSON, R. [ed.] (1993). National Innovation Systems: A Comparative Study. Oxford University Press, Oxford.

NELSON, R. (1995). Recent evolutionary theorizing about economic change, Journal of Economic Literature, Vol.33, pp. 48-90. 
NELSON, R., Sampat, B. (200I). Making sense of institutions as a factor shaping economic performance. Journal of Economic Behaviour and Organisation, Vol.44, Pp.3I-54.

NELSON, R., Winter, S. (1982). An Evolutionary Theory of Economic Change. The Belknap Press of Harvard University Press, Cambridge.

NONAKA, I. (1991). The Knowledge Creating Company. Harvard Business Review, Vol. 6 9(November-December), pp. 96-104.

NONAKA, I. (1994). A Dynamic Theory of Organizational Knowledge Creation. Organization Science, Vol.5, pp. I437.

NONAKA, I., Takeuchi, H. (1995). The Knowledge Creating Company: How Japanese Companies Create the Dynamics of Innovation. Oxford University Press, Oxford.

NORTH, D. (199I). Institutions. Journal of Economic Perspectives, Vol.5, pp. 97-II2.

OHMAE, K. (1990). The Borderless World. Harper Business, New York.

PISANO, G. (2006). Profiting from innovation and intellectual property revolution. Research Policy, Vol. 35. Pp. II22-II30.

PORTER, M. (1990). The Competitive Advantage of Nations. New York: Free Press.

QUINN, J. (1992). Intelligent Enterprise. Free Press, New York.

SCHUMPETER, J. (1934). The Theory of Economic Development. Harvard University Press, Boston.

SCHUMPETER, J. (1942). Capitalism, Socialism, and Democracy. Harper and Brothers, New York.

SHARIF, N. (2006). Emergence and development of the national innovation systems concept. Research Policy, Vol.35, pp. 745-766.
TEECE, D. (1986). Profiting from technological innovation. Research Policy, Vol.I5, pp. 285-306.

WESTERFILED, R.E. (ed.), (2004). Current Issues in Globalization. Nova Science Publishers, Inc, New York.

WU, J., Pangarkar, N. (2006). Rising to the global challenge: Strategies for firms in emerging markets. Long Range Planning, Vol.39, pp. 295-313.

\section{About the Authors}

Woojin Yoon is visiting researcher of the Institute of Management Research at the Seoul National University and a researcher of the Institute for Business Research \& Education at the Korea University. He holds BS and MS degree in business administration (both from Yonsei University) and $\mathrm{PhD}$ in strategic management and international business (from Seoul National University). Dr. Yoon has published his works in journals such as Korean Management Review and International Business Journal. His research interests focus on organizational learning, technology management \& innovation, organizational identity \& resource mobilization.

Eunjung Hyun received her BA degree at University of Warwick with a major in politics \& international studies and MS degree at University of London with a major in management \&organizational behaviour. Now she is a $\mathrm{PhD}$ candidate in the department of organizations and markets at University of Chicago. Her research interests include social networks \& innovations and economic development. 